\title{
Effect of Thermal Hydrolysis on Anaerobic Digester Performance
}

\author{
Leyla Amiri, Mohammad Ali Abdoli and Naser Mehrdadi \\ Department of Environmental Engineering, University of Tehran, \\ \#15 Ghods St, Enghlab Ave, Tehran, Iran \\ Corresponding Author: Leyla Amiri <Leila.amiri63@gmail.com>
}

Received 6 May 2014; Accepted 2 November 2014;

Publication 19 March 2015

\begin{abstract}
Anaerobic digestion (AD) has been recently introduced as a promising technology for producing bioenergy around the world. Due to its especial characteristics, solid waste could be considered as a proper feedstock in the digester. Retention time (RT) and rate of biogas production are two major parameters affecting the efficiency of the process. The AD procedure of biogas production consists of hydrolysis, acidogenesis, acetogenesis, and methanogenesis such that feeding materials would be processed inside the digester. The experiments have been carried out using two bioreactors with volume of 5 liters in mesopihilic contitions at $35 \pm 1{ }^{\circ} \mathrm{C}$. The purpose of this study is to accelerate the hydrolysis step. Pretreatment of the waste is accomplished using thermal hydrolysis in conditions of $155^{\circ} \mathrm{C}$ and $5 \mathrm{~atm}$. The results of this research indicated $33.33 \%$ decrease in RT and $154.87 \%$ increase in amount of biogas production using pretreatment process in comparison without considering it.
\end{abstract}

Keywords: Anaerobic Digester, Organic solid waste, Thermal Hydrolysis, Biogas.

Journal of Green Engineering, Vol. 4, 235-244.

doi: 10.13052/jge1904-4720.434

(c) 2015 River Publishers. All rights reserved. 


\section{Introduction}

The amount of solid waste generated in Tehran, as a capital city of Iran, has been increasing steadily over the last decade. In 2012, the average amount of waste produced was 2.7 million tons/year [1]. Therefore, innovative solutions require diminishing its impacts on environmental quality and public health. Anaerobic processes have been widely used in waste treatment for over a century. Nowadays, it is also used for energy recovery from organic wastes such as garbage by methane production using one- or two-phase fermentation systems [2,3]. Also anaerobic digestion (AD) has been used worldwide for over 100 years to stabilize wastewater solids [4]. Global concerns over energy security and greenhouse gases have given rise to the search for alternative energy source [5].

Developing biomass-to-biofuel technology could be significantly beneficial for enhancing energy security, reducing greenhouse gas emissions, and utilizing the renewable resources [6].

$\mathrm{AD}$ is extensively used as an alternative energy source from various biodegradable wastes. The $\mathrm{AD}$ produces biogas includes a methane and $\mathrm{CO}_{2}$ which is suitable for energy production. The byproduct, from the AD process can be used as fertilizer for agriculture. Methane, a valuable source of energy, is the primary biogas produced by anaerobic processed [7]. AD process is a well established process for treating many types of organic wastes, both solid and liquid [8-10].

In order to the best manage of anaerobic digesters should put them under constant state conditions. For example, various parameters affect on its performance. These factors include $\mathrm{pH}$, temperature, retention time (RT), loading rates and characteristic of substance.

AD of municipal solid waste were widely used in the world [11-13], but fewer research was done on enhancement of AD by using thermal hydrolysis.

There are numerous methods for pretreatment of solid particles in AD such as mechanical crumbling methods, chemical treatment, ultrasonic technique; thermal pretreatment, enzymatic pretreatment, electrical and freeze/thaw methods [14-17]. Thermal hydrolysis is a well proven method to remarkably increase the solubility of organic matter. It involves heating of the substance, usually to a temperature in the range of $150^{\circ} \mathrm{C}$ to $200^{\circ} \mathrm{C}$. The pressures adjacent these temperatures are in the range of 5atm to 20atm [18].

This process produces a material with the solvent molecules that are more readily available and can be disintegrated in anaerobic digesters. The Porteous 
process and the Cambi process are examples of thermal hydrolysis concepts which were previously implemented on many sites worldwide [19, 20].

Comparing TH with other technologies shows that it is a continuously operated technology involving high and controlled pressure and temperature. Even though differences in system arrangement such as temperature, pressure, time, characteristic of waste and pilot scale have confirmed expected benefits in energy recovery from enhanced digestion performance.

The AD of organic material basically follows four steps. These include hydrolysis, acidogenesis, acetogenesis and methanogenesis [21]. The thermal hydrolysis process is expected to accelerate and anticipates the first step of the anaerobic process and break the long chain molecules into an easily digestible feed for anaerobic digestion. The second effect is considered by a transfer indissoluble products towards degradable compounds and also killing pathogens.

However, special effects of thermal hydrolyses depend on waste characteristics and instrument and duration of this situation on materials.

The use of $\mathrm{AD}$ in cooperation with thermal hydrolysis has shown to produce improved VS removal, COD removal and greater biogas production [22].

Thermal hydrolysis is a process that uses heat and pressure as a substitute for biological hydrolysis. There are several advantages to this process. First and the main advantage of the process is that thermal hydrolysis can be accomplished in approximately 30 minutes as opposed to multiple days for passing the hydrolysis step in digestion.

Second, it is known for its highly efficient for destroying pathogens. Third, and maybe most important of the thermal hydrolysis process is that the solids concentration in the feed can be increased to 10 to $12 \%$ solids. This is in contrast to a practical limit of $7 \%$ for unhydrolyzed solids and allows a more concentrated feed to take place.

\section{Materials and Methods}

Municipal solid waste has been applied as feeding materials in this research. Based on the composition of the feedstock and considering the purpose of the study which is tracking the effect of hydrolysis temperature and comparing with normal digestion, the same type of organic compounds should be used in both bioreactors. As a consequence, the waste materials provided from a specific source and placed in a plastic container sealed enough to prevent any emission. Due to criticality of quality and quantity of organic materials, 
measuring of Total Solid (TS) and Volatile Solid (VS) was carried out before starting the digestion process which the results are demonstrated in Table 1.

The experiments were done in two anaerobic glassy digesters with capacity of 5 liters. The cylindrical digesters are made up of double-glass layer which assure its sealing against any heat exchange with the environment. By this way, the temperature of inside of digester could be kept constant. The digesters have height of $30 \mathrm{~cm}$ and inner diameter of $15 \mathrm{~cm}$. The process took place in the same environmental conditions (i.e., solid concentration of $8 \%$, temperature of $35 \pm 1{ }^{\circ} \mathrm{C}$ ) for both digesters. The materials stirred completely in order to provide homogenous feeds. The batch-load digester loaded and filled just at the first of the test and didn't reload by any input material during the test. A heating plate was used to preserve the temperature of the material inside the digester. The loading process was done using a magnetic stirrer in order that avoid over limitation of $8 \%$ solids as maximum allowed.

Stirring material in the digester not only stimulates microorganisms but also produce more gas subsequently. Digesters were investigated at time intervals of one month and averagely once in each $12 \mathrm{hr}$. In addition, rate of gas production was measured, recorded and finally discharged.

$5 \mathrm{~kg}$ of organic material with a moisture content of $54 \%$ was sampled and delivered to laboratory. The samples preserved in condition of $155^{\circ} \mathrm{C}$ and pressure of $5 \mathrm{~atm}$ for 30minutes and then was placed in plastic reservoir with appropriate lid and prepared for loading in digesters. Next, $1 \mathrm{~kg}$ organic waste together with 2 lit of water added into the digesters. The first digester was loaded with normal organic material and second one loaded by thermal hydrolyzed organic waste.

By a magnetic stirrer and a heating plate at the bottom of the digester, digesters got warmed up and materials in digesters were mixed. Produced gas went gradually to storage tank with floating dome and fixed gas pressure equal to $1.07 \mathrm{~atm}$. Storage tank which consists of two tanks with diameters of $12 \mathrm{~cm}$ and $13 \mathrm{~cm}$ and height of $20 \mathrm{~cm}$ placed upside down on each other and discarded $10 \mathrm{~cm}$ water in bottom of the tank.

Table 1 Qualitative and quantitative characteristics of municipal solid waste

\begin{tabular}{lcc}
\hline Parameter & Amount $(\mathrm{Kg})$ & Percentage from Total \\
\hline Average municipal solid waste & 1000 & 100.00 \\
Average home solid waste & 830 & 83.00 \\
Average biodegradable solid waste & 538 & 53.79 \\
Average total solid (TS) & 66 & 6.59 \\
Average total volatile solid (VS) & 43 & 4.34 \\
\hline
\end{tabular}


The displacement of the surface water between the two cylinders is a sign of the volume of gas production.

The upper tank was controlled by lightweight aluminum tubes which prevented its extra rising and collapse. Body of gas storage tank graded in centimeter and movement of water between two glass cylinders measured continuously in each $12 \mathrm{hr}$ and then the output data registered.

During the experiments at 3 days, 7 days, 15 days and 21 days after start of the experiment, sampling was carried out from produced gas in outlet of each digester. Analysis of the samples was finally performed using gaschromatography (GC-14B made by Shimadzu) apparatus. It should be noted that sampling did by special syringe of GC.

\section{Results and Discussion}

Doing described tests yielded the results that showed a decline RT in the first digester with normal organic waste and second digester with hydrolyzed organic waste to 20days and 15days, respectively (Figure 1-2).

Morgan-Sagastume et al., 2011, have reported that the efficiency of the process varied moderately with increase in temperature but the change in RT was seen to have a greater impact on the digester's performance [23]. Also the biogas produced from one kilogram of organic material in the first and second digester is 321.01 liters and 497.15 liters, respectively.

Some researchers have reported that thermal hydrolysis pretreatment [24-27] have been shown to have a positive effect on either the solubilization of organic material.

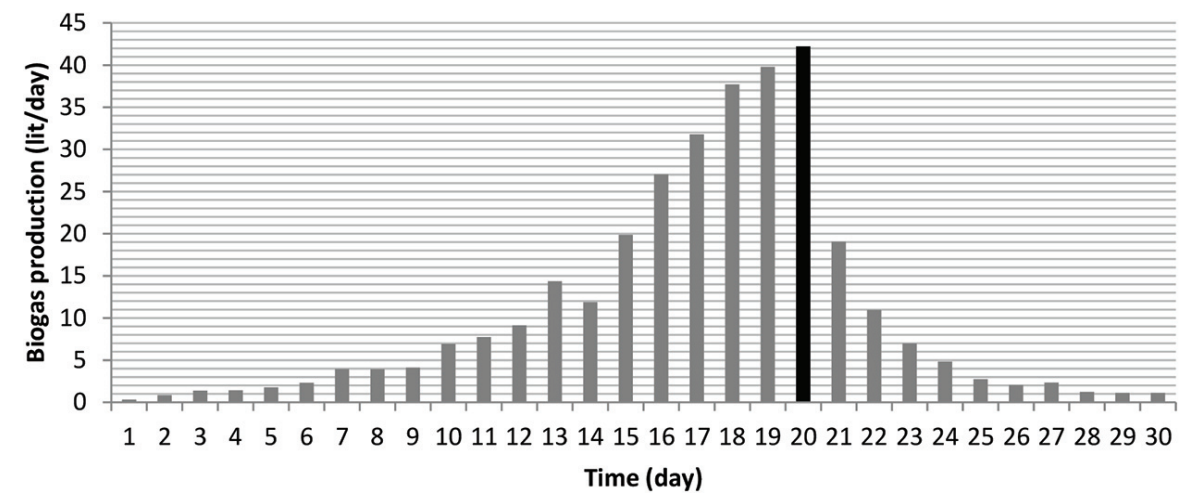

Figure 1 The biogas produced in the first digester during the 30-day trial. 


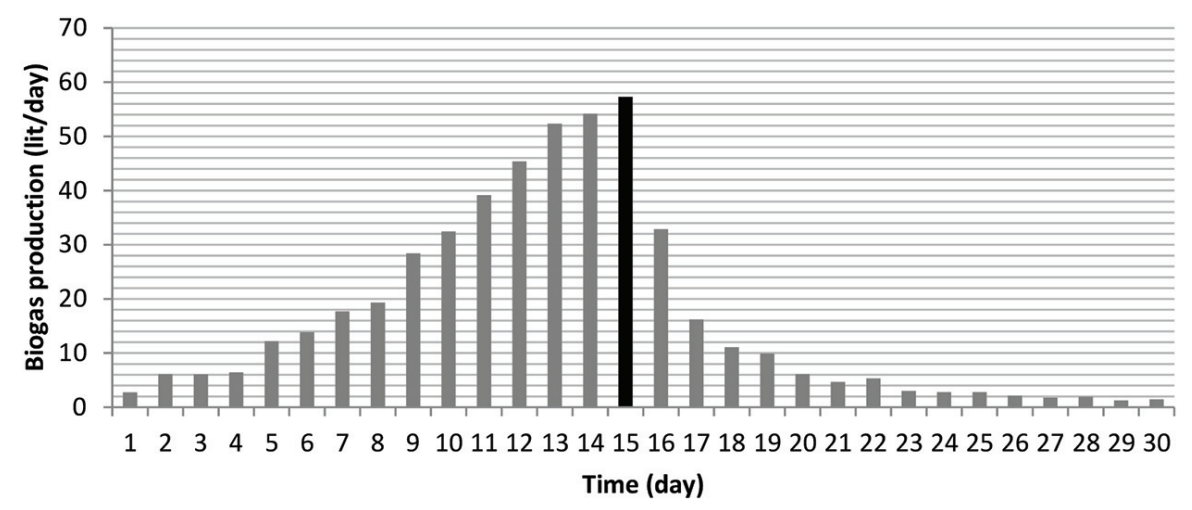

Figure 2 The biogas produced in the second digester during the 30-day trial.

According to the gas sampling in different days during the experiment and analyzing samples with GC results in Table 1 were obtained. Gas sampling has been taken from a plastic tube connected digester to gas storage tank for the lowest error analysis. The results obtained from this study have revealed that biogas produced in the second digester has higher and better quality than first digester and amount of methane up to $72 \%$ has been recorded (Table 2). High methane in biogas means an increase in the thermal value and better efficiency in digester.

Various authors have studied the effects of thermal hydrolysis treatment on the solid waste and sludge. While, all studies make known that thermal hydrolysis as a pretreatment has an optimistic impact on anaerobic digestion, it has also been observed that the hydrolysis conditions play an essential task in determining the efficiency of the process [28]. It had been reported that Thermal pretreatment in the temperature range from $100^{\circ} \mathrm{C}-180^{\circ} \mathrm{C}$ destroys cell walls and makes the proteins accessible for biological degradation [29].

Table 2 Characteristics of biogas in first and second digester

\begin{tabular}{rcccccc}
\hline Day & \multicolumn{3}{c}{ First Digester } & \multicolumn{3}{c}{ Second Digester } \\
\hline & $\mathrm{CH}_{4}$ & $\mathrm{CO}_{2}$ & $\mathrm{~N}_{2}$ & $\mathrm{CH}_{4}$ & $\mathrm{CO}_{2}$ & $\mathrm{~N}_{2}$ \\
3 & $36 \%$ & $45 \%$ & $4 \%$ & $49 \%$ & $37 \%$ & $4 \%$ \\
7 & $45 \%$ & $40 \%$ & $5 \%$ & $62 \%$ & $31 \%$ & $4 \%$ \\
15 & $55 \%$ & $28 \%$ & $3 \%$ & $72 \%$ & $24 \%$ & $2 \%$ \\
21 & $63 \%$ & $22 \%$ & $3 \%$ & $68 \%$ & $23 \%$ & $3 \%$ \\
\hline
\end{tabular}




\section{Conclusions}

The greater than before demand for highly developed techniques in AD over the last few years has led to the employment of various pretreatment methods prior to AD to raise gas production. Experimental results indicate that the use of thermal hydrolysis as a pretreatment for anaerobic digester feed material reduced RT of $33.33 \%$ and this result means significantly reduces for the required land and facilities needed to digest defined amounts of organic waste and it will also seek to increase public acceptance of this technology. In the other hand, the biogas produced from one kilogram of organic material on the thermal hydrolysis is significantly increased $154.87 \%$. Other achievements of this study increase quality of biogas produced in second digester which is loaded with hydrolyzed material, $72 \%$ was recorded for methane content in biogas produced in this digester which is considered an appropriate result.

In addition to all the good effects of thermal hydrolysis on the anaerobic digester efficiency, destroy pathogens in the waste caused by the high temperature pretreatment another one of the advantages of using this technology. As a result the digested material that is brought out of the digester can easily be used as fertilizer in agriculture.

\section{References}

[1] Tehran Organization of Waste Recycling and Composting, (2013).

[2] Hong, F., Tsuno, H., Hidaka, T., and Cheon, J. H.: Study on applicability and operation factor of thermophilic methane fermentation to garbage treatment in high concentration under.

[3] Park, Y., Hong, F., Cheon, J., Hidaka, T., and Tsuno, H.: Comparison of thermophilic anaerobic digestion characteristics between single-phase and two-phase systems for kitchen garbage treatment. J. Biosci. Bioeng., 105, 48-54 (2008).

[4] Van Lier, J. B., Tilche, A., Ahring, B. K., Macarie, H., Moletta, R., Dohanyos, M., Hulshoff Pol, L. W., Lens, P., Verstraete, W., 2001. New perspectives in anaerobic digestion. Water Science \& Technology 43 (1), $1-18$.

[5] Midilli A, Dincer I, Ay M. Green energy strategies for sustainable development. Energy Policy 2006;34(18):3623e33.

[6] Weizhang Zhong, Zhongzhi Zhang, Wei Qiao, Pengcheng Fu, Man Liu. Comparison of chemical and biological pretreatment of corn straw for 
biogas production by anaerobic digestion. Renewable Energy 36 (2011) $1875 \mathrm{e} 1879$

[7] Kassam Z. A., Yerushalmi L., Guiot S. R. (2003) A Market Study on the Anaerobic Waste-water Treatment Systems. Water, Air \& Soil Pollution 143:179-0-192.

[8] Borzacconi L, Lṕez I, Viñas M. Application of anaerobic digestion to the treatment of agroindustrial effluents in Latin America. Water Sci Technol 1995;32:105-11.

[9] Murto M, Bjornsson L, Mattiasson B. Impact of food industrial waste on anaerobic co-digestion of sewage sludge and pig manure. J Environ Manag 2004;70:101-7.

[10] Yen HW, Brune DE. Anaerobic co-digestion of algal sludge and waste paper to produce methane. Bioresour Technol 2007;98:130-4.

[11] Hartmann, H., Ahring, B. K., 2005. Anaerobic digestion of the organic fraction of municipal solid waste: influence of co-digestion with manure. Water Research 39 (8), 1543-1552.

[12] Davidsson, A., Gruvberger, C., Christensen, T. H., Hansen, T. L., Jansen, J. la C., 2007. Methane yield in the source-sorted organic fraction of municipal solid waste. Waste Management 27 (3), 406-414.

[13] Comino, E., Rosso, M., Riggio, V., 2009. Development of a pilot scale anaerobic digester for biogas production from cow manure and whey mix. Bioresource technology 100, 5072-5078.

[14] Komaki, H., Yamashita, M., Niwa, Y., Tanaka, Y., Kamiya, N., Ando, Y., Furuse, M., 1998. The effect of processing of Chlorella vulgaris: K-5 on in vitro and in vivo digestibility in rats. Anim. Feed Sci. Technol. 70, 363-366.

[15] Janczyk, P., Franke, H., Souffrant, W. B., 2007. Nutritional value of Chlorella vulgaris: effects of ultrasonication and electroporation on digestibility in rats. Anim. Feed Sci. Technol. 132, 163-169.

[16] Carrère, H., Dumas, C., Battimelli, A., Batstone, D. J., Delgenès, J. P., Steyer, J. P., Ferrer, I., 2010. Pretreatment methods to improve sludge anaerobic degradability: a review. J. Hazard. Mater. 183, 1-15.

[17] Carlsson, M., Lagerkvist, A., Morgan-Sagastume, F., 2012. The effects of substrate pre-treatment on anaerobic digestion systems: a review. Waste Manage. (Oxford) 32, 1634-1650.

[18] Abdoli, M. A., (2009), Municipal solid waste management, University of Tehran publication, $3^{\text {rd }}$ edition.

[19] Kepp U., Machenbach I., Weisz N. and Solheim O. E. (2000) Enhanced stabilization of sewage sludge through thermal hydrolysis - three years 
of experience with full scale plant. Water Science and Technology, 42 (9), 89-96.

[20] Neyens E. and Baeyens J. (2003) A review of thermal sludge pretreatment processes to improve dewaterability. Journal of Hazardous Materials, 98(1), 51-67.

[21] Grady, C. P. Leslie, Daigger, Glen T., Lim, H. C., Biological Wastewater Treatment, Marcel Dekker, New York, 1999.

[22] Camacho, P., Ewert, W., Kopp, J., Panter, K., Perez-Elvira, S. I., Piat, E. Combined experiences of thermal hydrolysis and anaerobic digestion latest thinking on thermal hydrolysis of secondary sludge only for optimum dewatering and digestion. Water Environment Federation, WEFTEC 2008.

[23] Morgan-Sagastume, F., Pratt, S., Karlsson, A., Cirne, D., Lant, P., Werker, A., 2011. Production of volatile fatty acids by fermentation of waste activated sludge pretreated in full-scale thermal hydrolysis plants. Bioresour. Technol. 102, 3089-3097.

[24] Bougrier, C., Delgenes, J. P., Carrere, H., 2008. Effects of thermal treatments on five different waste activated sludge samples solubilisation, physical properties and anaerobic digestion. Chemical Engineering Journal 139 (2), 236-244.

[25] Climent, M., Ferrer, I., Baeza, M. D., Artola, A., Vazquez, F., 2007. Effects of thermal and mechanical pretreatments of secondary sludge on biogas production under thermophilic conditions. Chemical Engineering Journal 133 (1-3), 335-342.

[26] Li, Y. Y., Noike, T., 1992. Upgrading of anaerobic-digestion of waste activated-sludge by thermal pretreatment. Water Science and Technology 26 (3-4), 857-866.

[27] Tanaka, S., Kobayashi, T., Kamiyama, K., Bildan, M. L. N. S., 1997. Effects of thermochemical pretreatment on the anaerobic digestion of waste activated sludge. Water Science and Technology 35 (8), 209-215.

[28] Wilson Christopher. A., Murthy, Sudhir N., Novak John T. Digestibility Study of Wastewater Sludge Treated by Thermal Hydrolysis. Residuals and Biosolids, pp. 374-386, 2008.

[29] Muller, J. A. Prospects and problems of sludge pre-treatment processes. Water Science and Technology, Vol. 44, No. 10, pp 121-128. 2001. 


\section{L. Amiri et al.}

\section{Biographies}

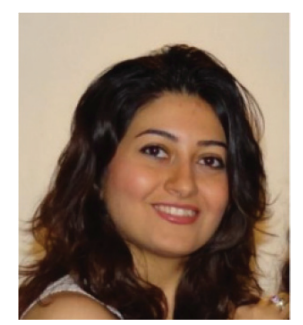

L. Amiri obtained her master degree in Civil-Environmental Engineering from University of Tehran, in 2009. Currently she is doing her PhD in Environmental Engineering in University of Tehran. Her areas of interests include waste to energy techniques, renewable energy and biogas.

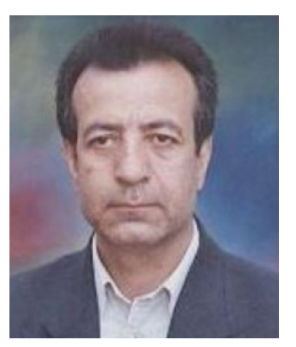

M. A. Abdoli obtained a PhD in Environmental Engineering, in 1982. Currently he is a full professor in University of Tehran. His research interests include solid waste management and waste to energy, biomass, renewable and sustainable energy.

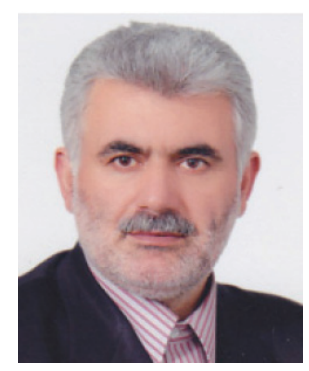

N. Mehrdadi obtained a PhD in Environmental Engineering, in 1994. Currently he is a full professor in University of Tehran. His research interests include waste water treatment and waste to energy, biomass and renewable energy. 